\title{
Exclusive breastfeeding counseling and free health checks as efforts to improve community healthy awareness
}

\author{
Azhari $^{*}$, Dara Maulida ${ }^{2}$, Firda Amalia Angkat ${ }^{2}$ \\ ${ }^{1}$ Department of Physics, Faculty of Mathematics and Natural Sciences, Universitas Sumatera \\ Utara, Medan, Indonesia \\ ${ }^{2}$ Faculty of Public Health, Universitas Sumatera Utara, Medan, Indonesia \\ *Email: azhari@usu.ac.id
}

\begin{abstract}
The success of exclusive breastfeeding is a high level of maternal education, a fairly high level of maternal knowledge, the existence of support and understanding of husbands to breastfeed exclusively, the role of potential groups to provide information to pregnant and breastfeeding mothers, the existence of counseling, supportive attitudes of officers and want to respond to every problem that is being faced. From the results of the study it is recommended to maintain and even increase and promote the success of exclusive breastfeeding. ASI is a fat emulsion in a solution of protein, lactose and organic salts that are secreted by the two glands of the mother's breast as the main and best food for infants because in the milk it contains immune, anti-infectious and nutritional nutrients needed to grow and develop and control excess weight gain. body or obesity. Exclusive breast milk is breast milk that is given to infants without additional food at least until the age of 4-6 months
\end{abstract}

\section{Keyword: Exclusive breastfeeding, Health}

\begin{abstract}
Abstrak
Keberhasilan pemberian ASI eksklusif adalah tingkat pendidikan ibu yang tinggi, tingkat pengetahuan ibu yang cukup tinggi, adanya dukungan serta pengertian suami untuk menyusui secara eksklusif, adanya peran kelompok potensial untuk memberikan informasi kepada para ibu hamil dan menyusui, adanya penyuluhan, sikap petugas yang suportif dan mau menanggapi setiap persoalan yang sedang dihadapi. Dari hasil penelitian disarankan untuk mempertahankan bahkan meningkatkan serta mempromosikan keberhasilan pemberian ASI eksklusif. ASI adalah suatu emulsi lemak dalam larutan protein, laktose dan garam-garamorganik yang disekresi oleh kedua kelenjar payudara ibu sebagai makanan utama dan terbaikuntuk bayi karena di dalam ASI terkandung zatzat kekebalan, anti infeksi dan nutrisi yangdibutuhkan untuk tumbuh kembang serta mengontrol terjadinya kelebihan berat badan atauobesitas. ASI Eksklusif adalah ASI yang diberikan pada bayi tanpa makanan tambahansekurang-kurangnya sampai umur 4-6 bulan
\end{abstract}

Kata Kunci: ASI ekslusif, kesehatan

\section{PENDAhULUAN}

Sarana kesehatan berada dekat dengan kediaman masyarakat. Desa Sei Siarti memiliki satu Puskesmas Pembantu dengan dua bidan desa. Pengobatan masyarakat dapat dilakukan dengan menggunakan BPJS atau pribadi. Masalah umum adalah tidak adanya tempat pembuangan akhir untuk sampah, sehingga wabah penyakit akan mudah datang pada masyarakat. Dikarenakan jauhnya akses ke pustu banyak masyarakat yang malas untuk berobat. Didalam pendahuluan tuliskan latar belakang, tujuan, dan manfaat.

Air Susu Ibu (ASI) Eksklusif adalah pemberian ASI tanpa makanan dan minuman lain. ASI Eksklusif dianjurkan sampai 6 bulan pertama kehidupan (Depkes RI, 2005). Manfaat dari pemberian ASI eksklusif sangat luar biasa. Bagi bayi, ASI eksklusif adalah makanan dengan kandungan gizi yang paling sesuai untuk kebutuhan bayi, melindungi dari berbagai infeksi dan memberikan hubungan kasih sayang yang mendukung semua aspek perkembangan bayi, termasuk 
kesehatan dan kecerdasan bayi.Bagi ibu, memberikan ASI secara eksklusif dapat mengurangi pendarahan pada saat persalinan, menunda kesuburan dan meringankan beban ekonomi (Roesli, 2008).

\section{METODE PELAKSANAAN}

Sebagai salah satu alat monitoring kesehatan bagimasyarakat untuk mendapatkan pelayanan kesehatan yang baik. Adapun pemeriksaan kesehatan meliputi pemeriksaan tekanan darah, Cek gula darah,asam urat, kolesterol, pengukuran TB,BB,dan lingkar pinggang. Membantu masyarakat untuk mendapatkan pemeriksaan kesehatan secara gratis dan mendeteksi adanya resiko penyakit sedini mungkin

Memberikan pengetahuan kepada ibu-ibu tentang apa itu ASI Eksklusif dan apa manfaatnya untuk bayi dan ibu. Mendorong ibu-ibu agar memberikan ASI Ekslusif sedini mungkin kepada setiap bayi yang berumur 0-6 bulan. Menambah wawasan ibu agar mengetahui bagaimana teknik atau cara menyusui yang baik dan benar. Agar ibu mau dan mampu memberikan ASI Eksklusif pada bayi yang berumur 0-6 bulan sesuai ketentuan yang berlaku dari KEMENKES. Para ibu mampu menjaga pola makannya untuk kepentingan gizi ibu dan bayi selama menyusui dan bayi mendapatkan kekebalan tubuh yang baik dari ASI ibu untuk pertumbuhan dan perkembangan si bayi selama belum mendapatkan makanan tambahan.

\section{HASIL DAN PEMBAHASAN}

Kegiatan Cek Kesehatan Gratis yang dihadiri oleh masyarakat desa dibalai desa. Dikarenakan oleh beberapa faktor, masyarakat didesa Sei Siarti sanagt malas untuk melakukan pemeriksaan sacara rutin ke pustu sehingga tidak sedikit masyarakat yang bersakit-sakitan. Dalam kegiatan ini, masyarakat dapat mengecek tinggi dan berat badan, dapat menghitung tensi darah, kadar gula darah, asam urat, dan kolesterol secara gratis. Dengan adanya kegiatan ini dapat membuka fikiran masyarakat agar lebih memperhatikan kesehatan mereka dengan melakukan pemeriksaan rutin ke pustu.
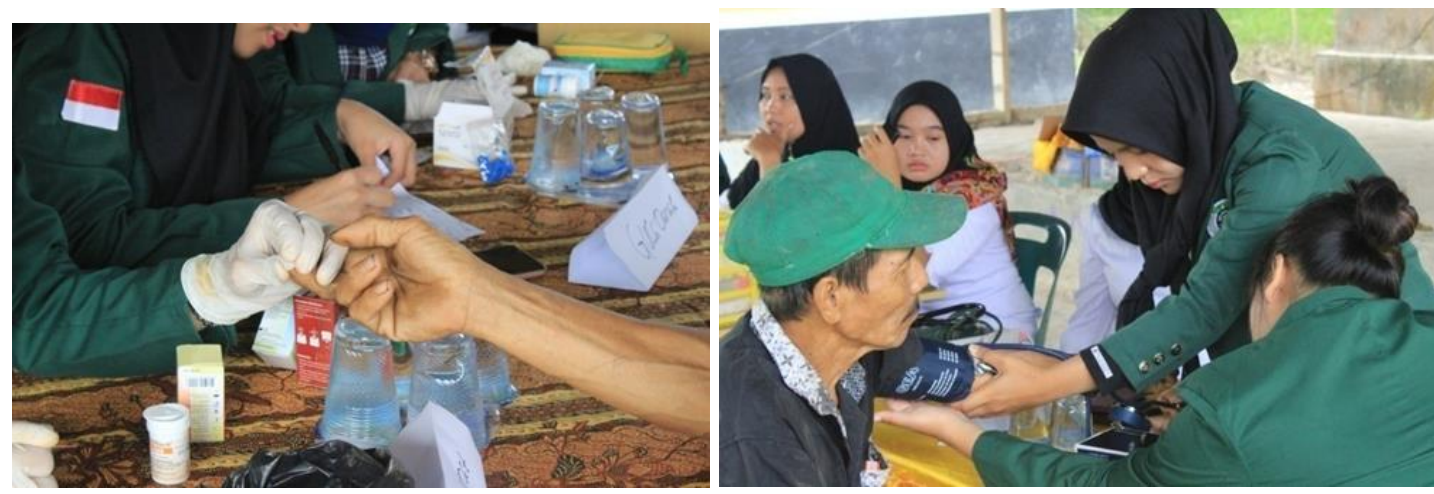

Gambar 3.1. Cek Kesehatan Gratis 

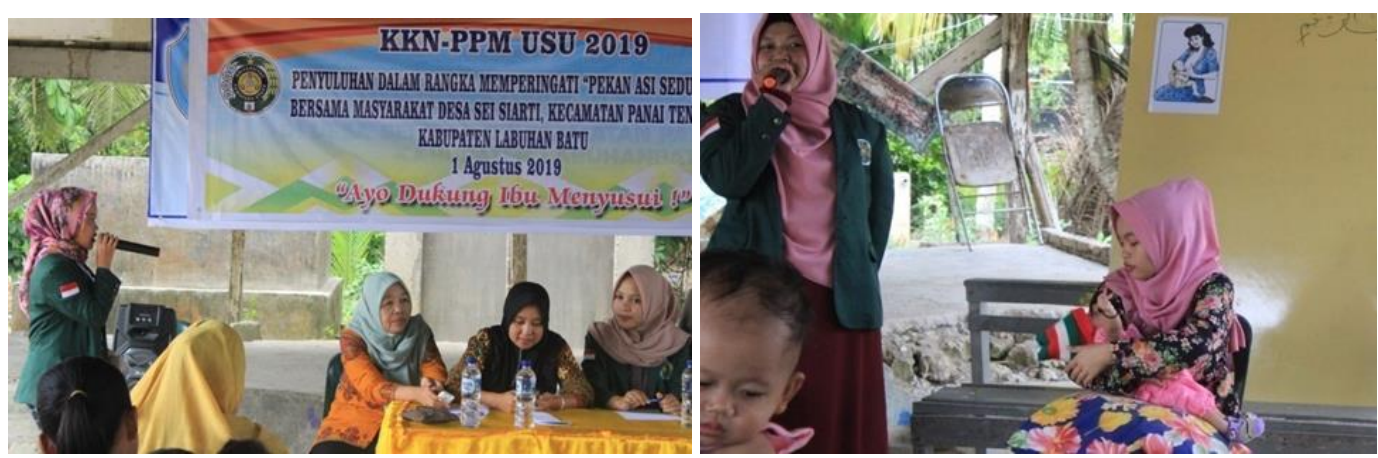

Gambar 3.2. Penyuluhan ASI Ekslusif

\section{KESIMPULAN}

Sebelum kegiatan pengabdian, masih banyak masyarakat tidak mengetahui pentingnya kesehatan dan ASI Ekslusif terhadap bayi. Oleh karena itu perlu diadakan nya penyuluhan atau pelatihan untuk ibu. Faktor lainnya adalah kurangnya sarana dan informasi yang didapat oleh masyarakat.. Setelah program pengabdian dilaksanakan, ibu-ibu mengetahui teknik menyusui dengan baik dan benar. Masih banyaknya ibu-ibu yang tidak mengetahui dedaunan yang dapat memproduksi ASI. Kurangnya pengetahuan masyarakat atas penyakit yang dideritanya, Dan diharapkan kepada seluruh masyarakat agarrutin melakukan pemeriksaan kesehatan. Untuk menjaga kesehatan dan mendeteksi penyakit sedini mungkin dan untuk meningkatakan kualitas hidup masyarakat

\section{UCAPAN TERIMAKASIH}

Pada kesempatan ini kami mengucapkan terima kasih kepada Rektor Universitas Sumatera Utara, Ketua dan Sekretaris Lembaga Pengabdian Pada Masyarakat USU dan Pegawai LPPM yang banyak membantu kegiatan pengabdian kepada masyarakat ini baik berupa moral maupun materiil

\section{DAFTAR PUSTAKA}

DepKes RI. 2005. Petunjuk Pelaksanaan Peningkatan ASI eksklusif: Departemen Kesehatan Republik Indonesia Jakarta

DinKes Provinsi Lampung. 2013. Laporan pemberian ASI Eksklusif Provinsi Lampung. Departemen Kesehatan Republik Indonesia. Jakarta

Lawrence, Green. 1980. Health Education Planning A Diagnostic Approach. Baltimore. The John Hopkins University. Mayfield Publishing Co.

Josefa, KG. 2011. Faktor-faktor yang Mempengaruhi Pemrilaku Pemberian ASI Eksklusif.Skripsi. Universitas Diponogoro. Semarang.

Komarsson KAC. 2008. Mother's knowledge about breastfeeding: a descriptive study. $O B J N$ vol $7 / 2$.

Kuzma J. 2013. Knowledge, attitude and practice related to infant feeding among women in rural Papua New Guinea: a descriptive, mixed method study. International Breastfeeding Journal 2013, 8:16 
Notoadmojo, S. 1997. Ilmu Kesehatan Masyarakat. Jakarta: PT. Rhineka Cipta. Roesli, Utami. 2005. Panduan Praktis Menyusui. Jakarta: Puspa Swara

Rusman.2008. Hubungan Tingkat Pendidikan dan Pengetahuan Ibu Dengan Pemberian ASI Eksklusif di Desa Selanggeng Purbalingga.Skripsi. Universitas Diponogoro. Semarang.

Seswita.2005.Pertumbuhan bayi yang menerima ASI Eksklusif dan Non Ekslusif di daerah perkotaan Sumatra Barat.Skripsi Padang. FKM Universitas Baiturrahmah.

Setyawati K. 2012. Hubungan Pengetahuan Ibu menyusui Tentang ASI Eksklusif degan Pemberian ASI Eksklusif di Desa Tajuk Kecamatan Getasan Kabupaten Semarang.Skripsi Universitas Kristen Setya Wacana. Semarang

Susanti R. 2000. Hubungan Tingkat Pendidikan Dan Pengatahuan Ibu Tentang ASI Dengan Penberian Kolostrum Dan ASI Eksklusif.Skripsi. Universitas Diponogoro. Semarang.

Syamsianah A,Muftenni, Mahardika DM. Hubungan Tingkat Pendidikan dan Pengetahuan Ibu Dengan Pemberian ASI Eksklusif dengan Lama Pemberian ASI Eksklusif Pada Balita Usia 624 Bulan di Kabupaten Pacitan Jawa Timur. Universitas Muhammadiyah Semarang. 